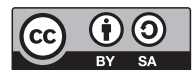

DOI 10.31261/IR.2021.06.07

\title{
FRANCE GRENAUDIER-KLIJN
}

Massey University (New Zealand)

iD

ORCID 0000-0003-2976-6993

\section{The post-shoah fiction of Anna Langfus (1920-1966): reader's positioning and empathic unsettlement}

Postholokaustowa twórczość Anny Langfus (1920-1966): pozycjonowanie czytelnika i empatyczny niepokój

Streszczenie: Urodzona w Polsce francuskojęzyczna pisarka żydowskiego pochodzenia — Anna Langfus (1920-1966) — jest autorką wielu tekstów o wysokiej wartości referencyjnej, literackiej, epistemologicznej i etycznej. Bohaterami jej trzech nowatorskich powieści, opartych na osobistym doświadczeniu utraty i wyobcowania, są osoby skrajnie wyalienowane. W utworach tych centralnym zagadnieniem jest tożsamość po Holokauście, a uwaga skupia się na wypowiedziach i doświadczeniach ocalałego. Jednocześnie stanowią one próbę nawiązania etycznego kontaktu z czytelnikiem, któremu, w odróżnieniu od bohaterów Langfus, obce są tego rodzaju traumatyczne przeżycia. Autor artykułu, korzystając z wprowadzonego przez Dominicka LaCaprę pojęcia „empatycznego niepokoju”, i przywołując opinie Langfus na temat literatury, omawia niektóre ze stosowanych przez nią chwytów narracyjnych (rezygnacja z patosu, luka, milczenie, elipsa), służących etycznemu apelowi do czytelnika.

Słowa kluczowe: Anna Langfus, reakcja odbiorcy, charakteryzacja, Dominick LaCapra, empatyczny niepokój

Постхолокостное творчество Анны Лангфус (1920-1966):

позиционирование читателя и эмпатическое беспокойствие

Резюме: Франкоязычная писательница еврейского происхождения, родившаяся в Польше - Анна Лангфус (1920-1966) — это автор многих текстов, обладающих высокой референциальной, литературной, эпистемологической и этической ценностями. Героями трех новаторских романов, основанных на личном опыте утраты, являются крайне отчужденные люди. Центральным вопросом в этих произведениях является идентичность после Холокоста, а основное внимание уделяется высказываниям и опыту выжившего. В то же время они представляют собой попытку установить этический контакт с читателем, которому, в отличие от персонажей Лангфус, чужды подобные травматические переживания. Автор статьи, используя концепцию «эмпатического беспокойствия» (Доминик ЛаКапра), и приводя мнения Лангфус о литературе, обсуждает некоторые из использованных ею повествовательных приемов (отказ от пафоса, лакуна, молчание, эллипс), служащих этическим обращениям к читателю.

Ключевые слова: Анна Лангфус, реакция читателя, характеризация, Доминик ЛаКапра, эмпатическое беспокойствие 
Literature seems to have precisely the task of telling what can be told in order to make perceptible, or at least palpable, what cannot be told'.

Only what cannot be said deserves to not be silenced ${ }^{2}$.

After the war, people will be tired; they'll be sick of it all... They'll want to forget as soon as possible and immerse themselves in fun and joy ${ }^{3}$.

On 18 May 1946, Anna Langfus arrived alone in Paris ${ }^{4}$, which would become her adopted city for the following twenty years she died prematurely on 12 May 1966 - and where she would become first a playwright and then a celebrated novelist. Born Anna Regina Szternfinkiel 26 years earlier, the only child in an affluent non-observant Jewish family from Lublin, Poland, nothing destined her for the world of writing. She married at the tender age of seventeen, her husband, Jakub Rajs, being only one year older. In 1938, the young couple moved to Verviers, Belgium, to study textile engineering with the intention of taking over the Rajs' factory upon completion of their studies. Anna and Jakub returned to Poland in 1939 for the summer holidays, only to find themselves caught up by History. The first two years of the war were spent at home with parents and in-laws. In March 1941, the two families were forced to move into the Lublin ghetto, where Anna's father was killed in April 1942. Desperate to flee Lublin, Anna arrived in Warsaw in March or April 1942, initially living and working in the ghetto, where she was treated for typhus, before escaping to the Aryan side of the city. She also resumed her activities as a liaison agent for the resistance organisation Armia Krajowa (the AK), with which she had been in contact since the beginning of the war. Maria Szternfinkiel, Anna's mother, seemed to have reached the Polish capital towards the end of 1942, hiding in various cellars and bunkers and escaping a number of Aktions before perishing in the burning of the ghetto in the wake of the 1943 uprising. As for Jakub, he arrived with his parents in May 1943 and reunited with

1 A remark made by László Tengelyi in a 2010 unpublished talk entitled The Theory of Narrative Identity Reconsidered, quoted by Sophie Galabru, Paul Ricceur and Emmanuel Levinas: vulnerability, memory and narrative, "Études ricœuriennes" 2019, vol. 10, no. 1, pp. 1-13.

2 E. Wiesel, Foreword, in: A. Insdorf, Indelible Shadows: Film and the Holocaust, Cambridge University Press, Cambridge 1983, pp. XI-XII.

3 A. Langfus, Les Lépreux (The Lepers), 1956. My translation. Unless otherwise indicated, all translations are mine.

4 The most complete and detailed account of Anna Langfus' life is to be found in Jean-Yves Potel's biographical essay: Les Disparitions d'Anna Langfus, Les Éditions Noir sur Blanc, Paris 2014. 
Anna. For the next 18 months, the couple lived a nomadic existence, going into hiding first in Warsaw itself, then in the woods to the north of the city, until their arrest by the Gestapo in December 1944. Imprisoned at Nowy Dwór Mazowiecki, Jakub was executed, and Anna tortured. She was then transferred to a prison in Płońsk until her liberation by Soviet forces in 1945. Most of these episodes found their way in Langfus' first novel, Le Sel et le Soufre (1960) (The Whole Land Brimstone, 1962), which was awarded the prestigious Swiss Charles-Veillon Prize for best novel in French.

After the war, Anna Rajs initially returned to her hometown of Lublin, even enrolling in a newly opened drama school, but the ubiquity of Polish antisemitism convinced her to leave Poland, as she recounted in an interview with Jeanine Delpech: "Yes, I left. I could no longer live in Poland. The vast majority of them knew. They knew and were accomplices in the slaughter. Sure, there were a few exceptions, a minority of people who remained upright and decent. But on the whole, what filth!" ${ }^{\prime 5}$. Midway through 1946, she decided to move to France where she initially taught mathematics in a Jewish orphanage in Rueil-Malmaison. In 1947, she married fellow survivor Aron Langfus. The following year, Anna and Aron had a daughter, named Maria (like Anna's mother and the protagonists of the first two novels ${ }^{6}$ ).

Pursuing her interest in theatre, Anna again enrolled in a drama school, this time to improve her mastery of French. This experience led to her first foray into fiction-writing, resulting in a play, Les Lépreux (The Lepers) first performed in December 1956. The play is concerned with the plight of Polish Jews during the Second World War, and the deleterious impact of Christian antisemitism. A mother, her daughter and two sons are hiding from the Nazis in an apartment procured by the Gentile wife of one of the sons. The arrival of the daughter-in-law's antisemitic father precipitates events and by the end of the play, only one family member has survived. The drama alludes to several episodes sadly familiar to the narrativation of the Shoah: ghettoization, deportation, collaboration, liquidation, denunciation, and the impact of antisemitism generally. In the last of its four acts, it even mentions the gas chambers and the Sonderkommandos of Auschwitz-Birkenau, one of the very first literary texts to do so. The taut and matter-of-fact narration, which includes the brutal and disturbing evocation of the murder of a very young child at the hands of a German soldier,

\footnotetext{
J. Delpech, Interview Anna Langfus, "Les Lettres françaises", 22 November 1962.

6 A. Langfus, Le Sel et le soufre, Gallimard, Paris 1960 (The Whole Land Brimstone, 1962); Les Bagages de sable, Gallimard, Paris 1962 (The Lost Shore, 1964).
} 
proved overtly confrontational for some audience members, who felt compelled to exit the theatre. As explained to Delpech, this was to be a turning-point for Anna Langfus' evolution as a writer:

To write Le Sel et le soufre, I could not simply tell the facts - the excess of horror would have made the book unreadable. I had seen spectators who, overcome by emotion, had left the room during a performance of Les Lépreux, and this urged me to caution and prompted me to always "keep it down" a notch?.

In effect, the reaction of these spectators was to shape the écriture of Anna Langfus, who, like other Shoah novelists, found herself subjected to two potentially conflicting imperatives. The first was a duty of faithfulness to those who did not survive the Holocaust and were therefore unable to narrate their own story: "I sensed that the matter was not whether I was going to write a good book or a bad one, but rather understanding that the book would be good only if I could remain faithful to a truth that I was not the sole custodian of ${ }^{\prime \prime}$. For Langfus, this deeply felt responsibility implied a need for truthfulness, exactitude and authenticity in the representation of what Paul Ricœur calls the ayant-été [the havingbeen], a term he coined to call us to remember the being-ness of those who-no-longer-are?

Such deontic attitude explains several narratological decisions on Langfus' part, which ought to be considered as both conscious and deliberate: the episodes related in all three novels are restricted to what she herself had experienced and/or witnessed first-hand; any form of victim rhetoric is rejected; there are no heroes; protagonists are 'imperfect' and flawed (harsh; selfish; brutal; cold). This latter stance, which I discuss in more depth below, is in keeping with the claim she made in her 1963 address to the Women's International Zionist Organization:

It is not according to whether they were good or bad that the Jews were persecuted, it is because they were Jews. [...] Some sought to wipe them from the face of the Earth, and one would not be able to evoke their tragic condition by depriving them of their share of human imperfection ${ }^{10}$.

At the same time, Langfus was driven by what we could call a duty of communicability, which explains also why she chose not

J. Delpech, Interview Anna Langfus...

8 A. Langfus, Un Cri ne s'imprime pas, Speech given to the Women's International Zionist Organization (WIZ0) in March 1963, reproduced in "Les nouveaux cahiers" 1993, vol. 115, pp. 42-48.

9 See in particular P. Ricœur, Temps et récit 1-'L'intrigue et le récit historique', Le Seuil, Paris 1991, and La Mémoire, I'histoire, I'oubli, Le Seuil, Paris 2000.

10 A. Langfus, Un Crines'imprime pas. ..., p. 47. 
to write an autobiography or a memoir. While such an exercise could have alleviated some of the trauma left by her experience of the war, bringing with it some personal "therapeutic" benefits, it would have failed to satisfy her deeply felt need for transmission of a horror that transcended her individuality:

Events that I had been involved in did not belong to me. In the end, even what I considered as my own personal experience, became one fragment of a larger experience. And from the moment I had decided to describe it, I had to assume a responsibility not only towards those who had gone through it with me, but also all those who would learn about it later ${ }^{11}$.

For Anna Langfus therefore, writing had to respond concomitantly to both self-expression and other-communication, s'exprimer and communiquer being but two sides of the same coin. However elusive, the figure of the reader, "more fictitious than a character in a novel"12, stood at the forefront of her novelistic considerations. Here, fiction-writing is tantamount to a welcome, an invitation to enter into a collective and communal space of human frailty, suffering, and values, Langfus' (ideal) reader being a conscious subject involved in an active process of (self-) reflection; as Angela O'Flaherty argues, she sought to create "responsible readers"13. Entrusting readers with such a task requires a delicate equilibrium between involvement and detachment: implicated, they must also resist identification. Encouraging and nurturing such reader-response is the task - perhaps even the duty - of the survivor-novelist, and this is where Langfus' attempt at "keeping it down a notch" becomes the most discernible.

In order not to ostracize her readers with confrontational, graphic descriptions, she instead used gaps, ellipses and the silence of characters, to represent what could not be said: "I wanted to tell the truth, but I was well aware that it was not possible for me to tell the whole truth, and that I would need to leave part of it in the shadow"14. A few years earlier, she had commented on silence serving as a vector for unspeakable truth: "Oftentimes, a scream can only be inscribed by way of silence. There needs to be a lot of silence in such books. Only then will the victims' laments, rage and fear be heard"15.

11 Ibidem, p. 42.

12 Ibidem, p. 43.

13 A. O'Flaherty, Anna Langfus's Les Bagages de sable, in: M. Atack; C. Lloyd (eds.), Framing Narratives of the Second World War and Occupation in France, 1939-2009, Manchester University Press, Manchester 2012, pp. 158-166.

14 A. Langfus, Un Crines'imprime pas..., p. 44

15 A. Langfus, De la difficulté pour un écrivain de traduire par la fiction la tragédie juive, "Information Juive", February 1961, p. 127. For a more detailed discussion of silence in Anna Langfus' œuvre, see also 
One of Langfus' most effective uses of silence is as a "bracketing device" to contrastively highlight the antisemitic discourse of talkative Gentiles who, believing themselves to be in the company of fellow anti-Semites, vent their spleen unfiltered ${ }^{16}$. In such instances, the intradiegetic (Jewish) listener's muteness not only operates as a resonance chamber enhancing the ignominious content of the "confession", it also confronts the reader with the raw violence of antisemitic rhetoric. Readers, particularly nonJewish ones, may never be able to fully comprehend the impact of antisemitism, however, the opposition of antisemitic volubility and Jewish muteness discourages comfortable ignorance and potential apathy. In so doing, Langfus gently presses upon them the very condition of their human-being-ness, susceptible themselves to become one day the target of hatred and discrimination. Endowing her characters with the capacity for a retort would have settled the matter, so to speak. Instead, Langfus exposes her readers to the "bare" antisemitic venom that marked the Jewish condition in Poland during the war, and so to an experience of wounding that is felt by the reader, not merely told to her/him. Not only might this encourage readers to "fill" the gap left by the diegetic listener's silence with their own outrage and compassion, it also bears stark witness to all those who could not or cannot speak in reply to the Shoah. In this way, Langfus' writing accords with David Patterson's claim that it is not only or simply because of their content that Holocaust novels disturb us, but rather "because they draw the reader into a position of responsibility, a position of vulnerability"17. Importantly, however, while, Langfus sought to encourage such responsibility and vulnerability in her readers, she adamantly rejected any overt manipulation of them, through the authorial "shock tactics" of exaggerated pathos, melodrama, sentimentalization or psychologization. And this is particularly noticeable at the level of characterisation, a feature of her écriture where she proves especially bold.

In her attempt at overcoming the obstacles presented by the writing of a topic which "exceeds both understanding and the possibility of traditional rhetoric ${ }^{\prime \prime 18}$, Langfus staunchly refused to

J. Friedemann, Langages du désastre. Robert Antelme, Anna Langfus, André Schwarz-Bart, Jorge Semprun, Elie Wiesel, Librairie Nizet, Saint-Genough 2007. See in particular Chapter V: Anna Langfus et les figures du silence, pp. 107-141.

${ }^{16}$ See for instance the episode with the priest's sister in Le Sel et le soufre who, assuming that Maria is also a Gentile, proceeds to narrate how she deliberately abandoned a young Jewish child in the woods.

${ }_{17}$ D. Patterson, The Shriek of Silence: A Phenomenology of the Holocaust Novel, University Press of Kentucky, Lexington 1992, p. 17.

${ }^{18}$ M. Ruszniewski-Dahan, Romanciers de la Shoah. Si l'écho de leur voix faiblit... L'Harmattan, Paris 1999, p. 40. But of course, this is a conclusion that virtually all commentators of Shoah literature have reached. 
turn her protagonists into heroes or martyrs ${ }^{19}$. In Le Sel et le soufre, her fictional alter-ego Maria brushes aside the courage required of her role as a courier for the Resistance, while in Saute, Barbara [Jump, Barbara] ${ }^{20}$, Michael repeatedly castigates himself for his past cowardice and proves similarly unsparing of fellow survivors. As critic Jean-Paul Dufiet has noted, "uncompromising and merciless, Anna Langfus often proves very harsh with her characters" Such dismissal of "goodness" is not uncommon in Shoah fiction, a "genre" ill-suited to oversimplified heroic figures, given the uncertain and morally complex environment which typifies such narratives. Furthermore, "although Holocaust literature is a reflection of recent history, it cannot draw upon timeless archetypes of human experience and human behaviour"22; and, as Myriam Ruszniewski-Dahan succinctly put it, "No protagonist can justly represent the six million"23. Anna Langfus' portrayal of tough and unforgiving protagonists further points to a degree of mistrust and wariness towards the edulcorating powers of literature. Reassured and soothed by admirable/lovable figures, would the reader not be dragged into a process of identification amounting to a second erasure of the ayant-éte of the Shoah? Indeed, the virulent refusal to provide such characters confirms that in Langfus' asserted belief a simplistic, binary, Manichean conception and representation of people in fiction about the Shoah was not only stylistically inept but also factually inaccurate and morally inappropriate:

One of the worse temptations a novelist dealing with the Jewish tragedy can yield to, is to paint things in black-and-white: the good - the persecuted - on one side, the bad on the other. Such an attitude can only arouse the reader's disbelief. A suffering man is not necessarily a saint. He is just a suffering $\operatorname{man}^{24}$.

By and large, her protagonist-narrators are not saints. They are deeply flawed individuals, who did not survive thanks to heroic actions and noble gestures, but often through sheer luck, selfishness, egocentrism or cowardice. In fact, these characters are oftentimes frankly disagreeable, a tendency which prevents the reader from being lulled into artificial compassion or demeaning pity: it

19 M. Cottenet-Hage, Anna Langfus et les risques de la mémoire, in: V. Engel (ed.), Les Lettres Romanes. Special issue: "La Littérature des camps: la quête d'une parole juste entre silence et bavardage", Louvain-la-Neuve 1995, pp. 25-39.

20 A. Langfus, Saute, Barbara, Gallimard, Paris 1965. [Jump, Barbara].

21 J.-P. Dufiet, Le Premier théâtre de la Shoah, Forum, Udine 2012, p. 13.

22 S. DeKoven Ezrahi, By Words Alone: The Holocaust in Literature, University of Chicago Press, Chicago 2008, p. 2.

23 M. Ruszniewski-Dahan. Romanciers de la Shoah..., p. 106.

24 A. Langfus, Un crines'imprime pas..., p. 47. 
is hard to like them, let alone feel sorry for them. As Madeleine Cottenet-Hage has shown, Langfus' denunciation of the disingenuousness of pathos is extended to the intradiegetic level; her protagonists overtly dread and berate (self)-pity ${ }^{25}$. It is as if for Langfus, any attempt at tugging at the reader's heartstrings in the context of Shoah fiction proved inherently kitsch, if not downright pornographic; a duplicitous manipulation of victims, survivors and readers; a betrayal.

Langfus depicts "normal" people, average individuals confronted with the radical dehumanization and deindividualization of the Shoah. Endowing them with less admirable traits illustrates her consideration of the ayant-été, those who have been, those who were, before the past, before death, whose being-ness was unquestionably marked by contingency, lacking, flawed, imperfect. Such a mode of characterisation answers the duty of faithfulness to victims of the Shoah that sparks Langfus' literary project; but it also responds to the duty of communicability extending to the reader. Just as the alliance of silence and direct speech allowed Langfus to maintain her focus on the reality of the Jewish experience of war, while simultaneously broadening, extending and universalising the ramifications of the story, the decision to weave her narrative around an obnoxious narrator or unpleasant characters preserves their ontological otherness, while encouraging the reader's responsible response. In effect, the reader is invited to "be with", not "be like", an ethical positioning which strongly echoes Dominick LaCapra's notion of "empathic unsettlement" to which we will now turn as a means of concluding.

In Writing History, Writing Trauma, LaCapra makes a passionate plea for empathy to be understood "in terms of an affective relation, rapport, or bond with the other recognized and respected as other"26. The essay advocates a new response to trauma, which LaCapra labels "empathic unsettlement", whereby "being responsible to the traumatic experience of others, notably of victims, [does not imply] the appropriation of their experience" ${ }^{127}$. The emotional response thus promoted "comes with respect for the other and the realization that the experience of the other is not one's own" ${ }^{\prime 28}$. While LaCapra here writes primarily for historians, the advocacy of such "ethical empathy" can be broadened

25 M. Cottenet-Hage, Anna Langfus et les risques de la mémoire..., p. 35.

26 D. LaCapra, Writing History, Writing Trauma, The Johns Hopkins University Press, Baltimore 2001, pp. $212-$ 213.

27 Ibidem, p. 41.

28 Ibidem, p. 40. 
to include readers of Shoah fiction. This might be particularly encouraged, as Emy Koopman argues, when the narrative "allows readers to understand the represented other [while simultaneously utilizing] disrupting techniques which make clear that understanding the other can never be complete ${ }^{\prime \prime 29}$. In my reading, Langfus' use of silence and less-than-sympathetic characterisation are instances of such "disrupting techniques"; they ensure readers can "feel with the other whom [they] do not know, may not understand, or even like" ${ }^{\prime 30}$. Anna Langfus' écriture disavows the pathos which promotes identification, a process which collapses the boundaries between individual identities, and therefore denies and suppresses the otherness of the other. Her writing enables the reader to apprehend the other's experience and viewpoint while retaining their own unique centre of gravity. Through the disruption created by gaps, silences, and the presence of an "unlikable" narrator-protagonist, her writing enables a response-able encounter to take place, which simultaneously preserves and alters the reader.

Anna Langfus' concern never was with creating a literal history. Nor did she conceive of literature as a didactic tool. She did not seek to educate her reader, but rather to communicate with her/ him in the fullest sense of that term as suggested above: extending them an invitation to enter a collective and communal space in which they, too, are vulnerable, wounded, and far from perfect. Her writing represents the impact that the traumatic events of war and violence have on human-beings, whomever they may be, and in so doing imparts some understanding to readers themselves foreign to the radical experience her literary alter-egos had endured. She achieves this by arousing her readers' innate ability to feel pain, sorrow, exclusion, loneliness, fear, anger or outrage, affects which form the basis of our shared humanity.

"Horror has its own language, and the voice of a man [read a writer] will always be too weak to render it" ${ }^{\prime \prime 1}$, Anna Langfus claimed. Yet, in drawing her readers into a mutual space of frailty and vulnerability, did she not succeed in reconquering and reclaiming but a small portion of the human-ness, the being-ness, the Shoah had denied? ${ }^{32}$

29 E. Koopman, Reading the Suffering of Others. The Ethical Possibilities of Empathic Unsettlement, "Journal of Literary Theory", January 2010, vol. 4, no. 2, pp. 235-251.

30 Ibidem, p. 243.

31 A. Langfus, Les écrivains devant le fait concentrationnaire, "L'Arche" 1961, vol. 50, p. 33.

32 My deepest thanks to my friend and colleague Dr Kim Worthington for the generous and astute comments and suggestions she provided with regards to an earlier version of this article. 


\section{References}

Cottenet-Hage, Madeleine. "Anna Langfus et les risques de la mémoire." Engel, Vincent (ed.). Les Lettres Romanes. Special issue: "La Littérature des camps : la quête d'une parole juste entre silence et bavardage. Louvain-la-Neuve 1995.

DeKoven Ezrahi, Sidra. By Words Alone: The Holocaust in Literature. Chicago: University of Chicago Press, 2008.

Delpech, Jeanine. "Interview Anna Langfus." Les Lettres françaises, 22 November 1962.

Dufiet, Jean-Paul. Le Premier théâtre de la Shoah. Udine: Forum, 2012.

Friedemann, Joë. Langages du désastre. Robert Antelme, Anna Langfus, André Schwarz-Bart, Jorge Semprun, Elie Wiesel. Saint-Genouph: Librarie Nizet, 2007.

Galabru, Sophie. "Paul Ricœur and Emmanuel Levinas: vulnerability, memory and narrative." Études ricœuriennes, vol. 10, no. 1, 2019.

Insdorf, Annette. Foreword by Wiesel, Elie. Indelible Shadows: Film and the Holocaust. Cambridge: Cambridge University Press, 1983.

Koopman, Emy. "Reading the Suffering of Others. The Ethical Possibilities of Empathic Unsettlement." Journal of Literary Theory, vol. 4, no. 2, January 2010.

LaCapra, Dominick. Writing History, Writing Trauma. Baltimore: The Johns Hopkins University Press, 2001.

Langfus, Anna. Les Lépreux [The Lepers]. Dufiet, Jean-Paul. Le Premier théâtre de la Shoah. Udine: Forum, 2012.

Langfus, Anna. Le Sel et le soufre. Paris: Gallimard, 1960.

Langfus, Anna. Les Bagages de sable. Paris: Gallimard, 1962.

Langfus, Anna. Saute, Barbara. Paris: Gallimard, 1965.

Langfus, Anna. "Un Cri ne s'imprime pas." Speech given to the Women's International Zionist Organization (WIZO) in March 1963. Reproduced in Les nouveaux cahiers, vol. 115, 1993.

Langfus, Anna. "Les écrivains devant le fait concentrationnaire." L'Arche, vol. 50, 1961.

O'Flaherty, Angela. "Anna Langfus's Les Bagages de sable." Atack, Margaret; Lloyd, Christopher. Framing Narratives of the Second World War and Occupation in France, 1939-2009. Manchester: Manchester University Press, 2012.

Patterson, David. The Shriek of Silence: A Phenomenology of the Holocaust Novel. Lexington: University Press of Kentucky, 1992.

Potel, Jean-Yves. Les Disparitions d'Anna Langfus. Paris: Les Éditions Noir sur Blanc, 2014.

Ricœur, Paul. Temps et récit 1-'L'intrigue et le récit historique'. Paris: Le Seuil, 1991.

Ricœur, Paul. La Mémoire, I'histoire, l'oubli. Paris: Le Seuil, 2000.

Ruszniewski-Dahan, Myriam. Romanciers de la Shoah. Si l'écho de leur voix faiblit... Paris: L'Harmattan, 1999. 